IRA-International Journal of Education \&

Multidisciplinary Studies

ISSN 2455-2526; Vol.12, Issue 01 (July, 2018)

Pg. no. 23-29.

Institute of Research Advances

http://research-advances.org/index.php/IJEMS

\title{
Exploring Sociocultural Structures that Generate Learner-Deviance within Murambinda Growth Point in Buhera, Zimbabwe
}

\section{Plaxcedes Chikunda}

Lecturer, Sociology of Education, Great Zimbabwe University, Zimbabwe.

Type of Review: Peer Reviewed.

DOI: http://dx.doi.org/10.21013/jems.v12.n1.p2

How to cite this paper:

Chikunda, P. (2018). Exploring Sociocultural Structures that Generate Learner-Deviance within Murambinda Growth Point in Buhera, Zimbabwe. IRA International Journal of Education and Multidisciplinary Studies (ISSN 2455-2526), 12(1), 23-29.doi: http://dx.doi.org/10.21013/jems.v12.n1.p2

(C) Institute of Research Advances.

\section{(cc) EY-NC}

This work is licensed under a Creative Commons Attribution-Non Commercial 4.0 International License subject to proper citation to the publication source of the work.

Disclaimer: The scholarly papers as reviewed and published by the Institute of Research Advances (IRA) are the views and opinions of their respective authors and are not the views or opinions of the IRA. The IRA disclaims of any harm or loss caused due to the published content to any party.

Institute of Research Advances is an institutional publisher member of Publishers Inter Linking Association Inc. (PILA-CrossRef), USA. The institute is an institutional signatory to the Budapest Open Access Initiative, Hungary advocating the open access of scientific and scholarly knowledge. The Institute is a registered content provider under Open Access Initiative Protocol for Metadata Harvesting (OAI-PMH).

The journal is indexed \& included in WorldCat Discovery Service (USA), CrossRef Metadata Search (USA), WorldCat (USA), OCLC (USA), Open J-Gate (India), EZB (Germany) Scilit (Switzerland), Airiti (China), Bielefeld Academic Search Engine (BASE) of Bielefeld University, Germany, PKP Index of Simon Fraser University, Canada. 


\begin{abstract}
Learner deviance is reportedly high in areas transforming from a rural to semi-urban setup. In Murambinda growth deviant activities were reportedly on the rise with learners involved in prostitution, drug and alcohol abuse, truancy, teenage pregnancy, hate speech, pornography viewing, careless talk and many more appear to be on the rise. The Functionalist perspective was used to explore learner deviance and Robert K. Merton's structural strain theory provided analytical tools to explore sociocultural structures that generate such learner deviance within Murambinda growth point. A case study approach was employed focusing on two secondary schools in the growth point. Data was gathered using interviews and observations to a sample of 20 teachers, 40 learners and ten parents. The major findings were that despite positive factors brought about by the establishment of the growth point, deviant activities that impede learning are on the rise. The imbalance, between cultural goals and structurally available means lead some learners into deviant behavior. The researcher recommended that similar studies should be carried out among schools in growth points in order to improve behavior and pass rate of secondary school learners in growth points. Policies should also look into remedying the situation.
\end{abstract}

Keywords: Socio-cultural, education, learning

\title{
Background and Context
}

The term 'growth point' according to Manyanhaire, Rwafa and Mutangadura (2011:1), entails increasing the size, number of facilities, infrastructure and services provided at an identified centre. Thus rural centres designated for such growth are commonly known as growth points in Zimbabwe. These centres are sometimes referred to as either 'growth centres' or 'growth poles'. Nhende (2013) describes a growth point as a rural or urban settlement with the potential to grow into a town and eventually into a city.

The prime objective behind the establishment of growth points in Zimbabwe was to even the dualistic and polarized economies between the rural and urban areas created by the white settlers regime (Manyanhaire, Rwafa, Mutangadura, 2011). The growth point strategy was also aimed at decongesting the urban centres as it was anticipated that the strategy would result in the decline of rural - urban migration (Nhede, 2013). Local industries and other business enterprises relocating to the designated growth points would create employment opportunities for local communities. The government was committed to bringing service delivery closer to the rural communities. This commitment can best be understood when viewed in relation to the promises made to rural communities during the armed struggle; that of providing better public service delivery to the marginalized rural communities (ibid). The new government of Zimbabwe in the early 80s had an obligation to correct the colonial social and economic imbalances through the promotion of equitable development. The mandate of the growth points was to lure investors who would in turn create much needed employment. As a result some potential job seekers would have alternative places from which to seek employment rather than relying only on urban centres. The assumption was that the establishment of growth points would allow an agglomeration of economic activities such as industries, commercial and trading functions and service functions (Sibanda 1985).

Murambinda growth point was established in the 80s just as most others in the country. It is located in Buhera district, Manicaland Province, eastern Zimbabwe. Its location is approximately 140kilometres, by road, west of Mutare, the location of the provincial headquarters. There are two secondary schools at the growth point and a referral missionary hospital. The current population of Murambinda growth point is estimated at 3383 .

Over the years the growth point has seen some developments similar to those in an urban set up, namely electricity supply, banks, supermarkets, night clubs, 24hour fast food suppliers and Drive Inns. A network of tarred and dust roads led to increase in traffic flow through the growth point. The growth point has attracted several economic activities such as metal work, welding, fence making and fabricating of scotch carts, vending, road and building construction and fruit and vegetable retailing. Most of these economic activities can be fairly done by semi-skilled workers.

The revolution of Murambinda from a rural setup to an urban centre has brought about massive transformation forces, as production is moved from a family unit to a business set up. The taking over of family's functions by commercial agencies and state organizations seem to erode the family's role as an institution that imparts norms and values to the young members of society. Failure by the family to play such a role has the potential to lead to deviance among learners. This has prompted the researcher to want to establish learners' deviant activities and to explore socio- cultural structures that generate learner deviance within Murambinda growth point. 


\section{Theoretical Focus}

Deviance consists of those acts that depart from the norms and expectations of a given culture. To deviate means to drift away from a conventional trail. From a functionalist perspective deviance breaks social norms and values (Haralambos and Holborn, 2013). Merton (1957) argues that deviance results from the culture and structure itself. Beginning from the standard functionalist position of value consensus, he posits that all members of society share the same values. In all societies, there are institutionalized means of reaching culturally defined goals. For instance in Zimbabwe, as in most other countries, the most acceptable way of achieving success is through attaining educational qualifications.

In his structural strain theory which is an extension of the functionalist perspective on deviance, Merton (1957) argues that the origins of deviance can be traced to the tensions that are caused by the gap between cultural goals and the means people have available to achieve those goals. According to the structural strain theory, societies are characterized by both culture and social structure. Culture establishes goals for people in society while social structure provides (or fails to provide) the means for people to achieve those goals (ibid). In a well-integrated society, people use accepted and appropriate means to achieve the goals that society establishes. In this case, the goals and the means of the society are in balance. It is when the goals and means are not in balance with each other that deviance is likely to occur. This imbalance between cultural goals and structurally available means can actually lead an individual into deviant behavior.

Merton presents the following typology of Deviance. According to Merton, people conform to either the opportunities or goals defined by society or they engage in five types of deviance as shown in Figure 1.

Conformity: The individual conforms to the dominant culture. Here the individual experiences no problem in terms of goals and the means that society provides to achieve those goals. There is, therefore, no need to engage in deviance to obtain goals deemed worthy by society.

Innovation: Innovators are people who accept the goals of society. For some reason, like poverty, they cannot achieve societies' goals by legitimate means. They have to use illegitimate means such as stealing.

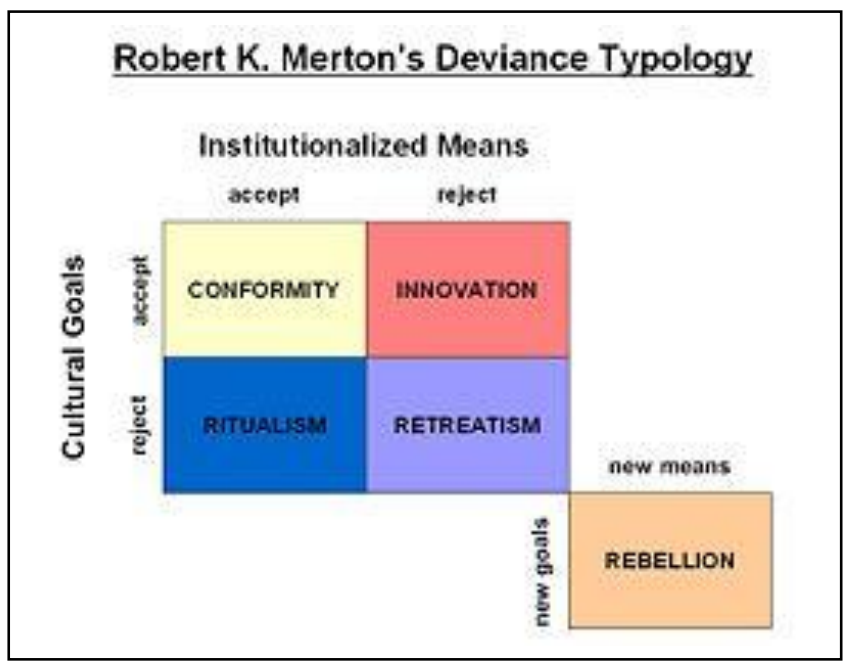

Ritualists: are individuals who do not believe in the established cultural goals of society, but they do believe in and abide by the means for attaining those goals. The individual may, for example, choose to work hard knowing that he or she is not going to achieve the goals that society defines as worthy because they do not get paid enough.

Retreatism: simply avoid both the goals and means established by society without replacing those norms with their own counter-cultural forces. Drug addicts and vagrants are examples of people who retreat.

Rebellion: Rebels not only reject both the established cultural goals and the accepted means of attaining those goals, but they substitute new goals and new means of attaining those goals. Included in this group are revolutionaries and some gangs.

Merton's typology raised some critique that is also useful to this paper. For instance Merton assumes that people who have access to legitimate means and goals automatically use legitimate means and goals. The drug challenges in affluent high schools in Zimbabwe demonstrates that people who have access to legitimate means still engage in deviance. Another example that contradicts Merton's claims is the large number of middle-class teenagers who shoplift goods in supermarkets. They do not engage in this activity because they do not have access to means and/or goals. They shoplift for different other reasons. 


\section{Review of Related Literature}

Literature has some attributes that may suggest social and cultural structures that can lead to learner deviance. For instance Bourdillon, White\&Myers(2009)examine the life of the children at a rural growth point. They noticed that due to economic hardships, school girls in townships are exposed to adulthood things and the world of money at a tender age, and this comes with vulnerability to various forms of abuse. They fall victim to teenage pregnancy, sexually transmitted diseases, while others engage in commercial sex work.

Studies abroad also show similar trends, for example in Sarawak in Malaysia, Aziz, Hassan, \& Saud, (2012) highlighted that urbanization results in massive transformation forces. They further highlights there are two camps with different views with regards to changes brought about by the development of growth point areas. The first camp put forward the notion that changes in the structure of the family is not a new phenomenon but that from time to time changes are seen in the family structure as adapts to changed circumstances. Thus, using this argument, the development of growth points will naturally lead to changes in family structures in and around the growth point as families begin to adapt to changes in the growth point. As a result, the behaviours of students (who are also part of the families) are also expected to naturally adapt to changes that come with the development of the growth point area. Aziz et al (2013) further point out that the other camp believes that changes in the behavior of people is a consequence of an irreversible breakdown in values. Breakdown in values results in child marriages, unwanted pregnancies, smoking and drinking amongst other students. Seccombe (2005) also complimented the view by highlighting that the taking over of family's functions by commercial agencies and state organizations had eroded the family's role as an institution. For instance argues that family forms and modes of production are closely enmeshed and the transformation of the former will follow closely on the heels of the latter (ibid). In other words, a certain mode of production will facilitate the reproduction of a certain family form while impeding the development of others.

According to Scott (1982) environments such as growth points and urban station lead to gradual erosion of family ties leading to illegitimate births in many European cities between 1750 and 1850 . Hove, Ngwerume. \& Muchemwa, (2013) argued that loneliness and isolation in the city added to the social pressure to either find a spouse or other means of generating income. Sadly in such circumstances the youth in growth points become exposed to premarital sex which will be given on the promise of marriage and an escape route to a better life. However, social mores that dictated courtship behavior in the villages are not enforceable in growth points or urban areas. Consequently many rural young women in secondary schools are caught unaware when they get exposed to the peri-urban environments.

Mwamwenda (2004) claims that misbehavior of a child depends on the way the child has been raised which is not congruent with the behavior expected by society. Language used by most vendors has a negative effect on their children and they copy that. Most vendors leave home early and come back home very late having no time for the children. According to Mwamwenda, frustration at home may lead to misbehavior. The way children live is often reflected by their behavior. Mwamwenda (1995) alludes that a child who does not receive love and good care from parents is likely to have no respect for them and may even extend this perception to all adults and other figures of authority including teachers. He further pointed out that parents are often unable to correct and control the children who transfer their way of relating at home to the school and society. The information provided by Mwamwenda (ibid) was very relevant to the study of the behavior of secondary school learners in growth points.

\section{Statement of the Problem}

Over the past few years, deviant activities of secondary school learners in Murambinda growth point seem to be increasing. Issues of prostitution, drug and alcohol abuse, truancy, teenage pregnancy, hate speech, pornography viewing, careless talk and many more appear to be on the rise. The study sought to establish learners' deviant activities and to explore social and cultural structures that lead to such deviance within Murambinda growth point.

\section{Objectives of the study}

The study was guided by the following objectives

i. to identify deviant activities that high school learners engage in Murambinda growth point.

ii. To explore sociocultural structures that lead to learner deviance within Murambinda growth point. 


\section{Methodology}

A case study design was adopted focusing on learners, teachers and parents. Two secondary schools in the growth point were the focus of the study. A total of 20 teachers, 40 learners and ten parents participated in the study. The participants were selected using a combination of convenient and stratified random sampling. Stratified random sampling was used to ensure that different groups of a population are adequately represented in the sample and in this case males and females as well as equal representation from the two schools. Non participatory observation, questionnaire and interviews were used to generate data. The observation method was used on learners so as to identify deviant activities that they engage in. Observation was done over a long period exceeding a year, and did not target specific individuals but capturing any behavior or practice that departed from the expected norm of a secondary school learner. The questionnaire was administered to 40 learners, 20 from each school. Questionnaire items helped us to triangulate data on deviant activities as well as soliciting information on potential sociocultural structures that lead to learner deviance within Murambinda growth point. Two types of interviews were employed, face to face in-depth with parents and focus group with teachers. Four focus group interviews were held, two per school. Interviews were held to triangulate data generated through observation and questionnaire.

\section{Findings and Discussions}

As highlighted above the study was guided by two objectives; to identify deviant activities that high school learners engage in and to explore sociocultural structures that lead to learner deviance within Murambinda growth point. Findings and discussions are reported under these two themes.

Observations showed that some learners around Murambinda growth point are engaged in numerous activities that are deemed deviant. These include prostitution, drug and alcohol abuse, truancy, use of abusive and careless talk, pornography viewing, hassling and disrespect and disobedience.

In focus group interviews a larger percentage confirmed that most girl learners are getting pregnant whilst at school and they drop out of school. Teachers and parents also echoed that a number of learners are testing HIV positive at Murambinda mission hospital. Parents concur with teachers that young ladies indulge in early sex. They echoed that learners are seen after hours wearing short skirts and shorts in night clubs and beer halls, something that we had observed on numerous occasions. Learners come for entertainment especially during weekends when musicians perform in the growth point. Learners reveal that they go for prostitution because they want to buy cell phones, flashy clothes and food. The findings also revealed that most learners wish to have a better life just like any other learner from well to do families. Using Merton's typology deviant learners are using several 'innovative' means to achieve their goals.

There are also a number of social and cultural structures that generate pressure for the above sex related deviant activities in Murambinda. For instance the growth point has a noticeable presence of sex workers whose livelihoods appeal to young people, fashionable clothes, hair style, latest cell phones and so forth. These influence young school girls to do the same in their quest to find cheap money. Heavy duty truck drivers and long distance buses operators lure school girls into sex related deviant activities. Despite various HIV and AIDS awareness campaigns and sex education programmes, young school going girls keep joining the world's oldest profession. The girls are taken to lodges around one of the country's vibrant growth points Murambinda, where they engage in commercial sexual activities. Poverty is also a driving force as revealed by teachers, parents and learners, that young girls are forced to sell their bodies in order to raise money for school fees and food.

I also observed a steady growth of gay gangsterism and homosexuality activities in the growth point, most of the gay members are between the ages of 15 and 22 years which is a secondary school aged group. Homosexuality is regarded as deviance in Zimbabwe. The growth point is also a playground of illegal diamond miners, popularly known as "magweja", a factor that seems to be influencing secondary school learners to indulge in homosexual activities. The other factor is that secondary school learners in Murambinda growth point have access to all media forms such as videos, internet, newspapers, magazines and WI-FI unlike their counterparts in other rural schools. I observed that while most learners take advantage of the media to support their studies, some use it for deviant activities such as viewing of pornographic material. Teachers, parents and learners also concurred that learners get to know a lot of the sexually related deviant activities through media. The three groups were of the opinion that electronic media influences learners to indulge in sex related activities leading to unplanned pregnancies and spread of HIV.Wegner (1993), also commented that media has the power to influence, shape, manipulate and manage public discourse associated with media. This could be attributed to the shocking deviant activities of learners in the growth point. 
Early marriages or child marriages is common in Murambinda with a significant number of school girls getting married and leaving school before the age of 18 years. United Nations defines child marriage as any marriage carried out below the age of 18 years, before the girl is physically, physiologically and psychologically ready to shoulder the responsibilities of marriage and child bearing (Narayana and Kantner, 2000). This constitutes a deviant act in the sense that society expects all children to complete at least secondary education before marriage. Child marriage is also a violation of children's human rights and is prohibited by international law, rob girls under 18 of their childhood (Voice of America 2016). Early marriage denies girls their right to make vital decisions about their sexual health and well-being. It forces them out of education and into a life of poor prospects, with increased risk of violence, abuse, ill health or early death.

While child marriage is widely known as a violation of children's rights, there are several socio-cultural structures that contribute to it in Murambinda. Poverty, religion and tradition are main reason. Of significance is the fact that the apostolic religious sect is dominant in the growth point. The sect believes in early marriage and they don't place any value in the education of the girl child. Teachers and parents also pointed out to religious beliefs as causal to child marriage. Poverty exacerbated by perennial poor harvests was raised by teachers and parents as another sociocultural driver that leads to child marriage. In the time of need some families opt to marry their daughter in order to get lobola that can see the family out of dire misery.

Focus group interviews with teachers revealed that learners who pass through the growth point and those who live in and around the growth point have a tendency of disobeying teachers. The teachers have been experiencing difficulties in disciplining these learners and do not complete their homework. Teachers stated that some of the learners come to school drunk and they smoke whilst they are in toilets. A larger percentage of the parents concurred with the teachers that some of the secondary school learners in the growth point lack respect and discipline. Parents also stated that these secondary school learners displayed disrespect before their parents as they move around in the growth point. A greater percentage of parents revealed that these learners smoke and drink alcohol without even respecting them. Secondary school learners below the age of 18 are seen in beer halls and in night clubs drinking alcohol and engaging in prostitution.

Several socio-cultural factors contribute to such disobedience. For instance, it was observed that owners of beer halls and night clubs do not restrain school learners from patronizing their business, as they are after their money. Some business owners even consider the presence of young girls in their night clubs as a positive factor to attract patrons, clearly disregarding societal norms, values and expectations.

The majority of the teachers confirmed that children use abusive language at school. Parents agreed with teachers' responses, confirming that a significant number of secondary school learners are bullies and they are rude. A larger percentage of the teachers interviewed echoed that the language used at Murambinda bus terminus and the flea market promotes the use of abusive language by learners. Bourdillon, (2000), asserts that some children who work at the bus terminus are exposed to all kinds of immoral behavior. Learners revealed that they are bully and violent because they copy from their elders in the growth point. They also watch violent movies, wrestling and horror movies in the night clubs. Patterson, Dishion, and Yoerger (2000) proposed that exposure to deviant peers may have particular salience to adolescents who do not initiate delinquent behavior until mid- to late-adolescence.

During the observation period I observed that a number of learners take part in economic activities even during school hours. Parents, Teachers and learners also confirmed that some learners take part in activities such as vending, laundering, sewing, beer brewing, making of handcrafts and textiles, joining food for work programmes. The three groups pointed out that some learners are involved in vending during the day and join prostitution during the night. Under normal circumstances, such economic activities are not expected to be carried out by school children. A decade of economic meltdown in the country has forced some secondary school learners to seek jobs and shelter at growth points where if they fail to get jobs and shelter they end up indulging in immoral activities so as to earn a living.

\section{Conclusion}

The study identified learner deviant activities and explored sociocultural structures that generate such deviance in Murambinda growth point. Findings revealed that learners are involved in numerous deviant activities which include prostitution, drug and alcohol abuse, truancy, use of abusive and careless talk, pornography viewing, hassling and disrespect and disobedience. These findings are in line with Ricci's(2012) argument which places much emphasis on the fact that growth points or peri-urban areas result in changes in values. In a rural set up, parents and village 
elders provide guidance to young people, unlike in a growth point where they are exposed to urban individualistic and pleasure-seeking values. The sudden change from a rural to an urban setup exposed learners to urban related pressures resulting in learners getting involved in the above mentioned deviant activities.

As recommendations, government should enforce laws that protect the learner against being used as child labour for example selling goods at growth points. Stiffer sentences should be imposed on parents or guardians who violate such laws. The government through the Ministry of Primary and Secondary Education should make sure that guidance and counseling is taught in secondary schools. This would empower learners with knowledge on how to deal with situations of abuse and other problems befalling them. There is also need to support learners financially for them to have a decent living. The researcher also recommends that the government should give stiffer penalties to those who violate the law which restricts children under the legal age of majority to enter into beer halls and night clubs.

\section{References}

[1]. Aziz. N, N, Hassan, W. H, \&Saud. A (2012).The Effects of Urbanization towards social and cultural changes among Malaysian Settlers in the Federal Land. Procedia - Social and Behavioral Sciences 68; 910 - 920.

[2]. Bourdillon, M. F.C.; White. B and Myers. W. E (2009).Re-assessing minimum-age standards for children's work. International Journal of Sociology and Social Policy. 29 (3/4),pp. 106-11

[3]. Bourdillon, M.F.C. (2000), "Child labour and education: a case study from south-eastern

[4]. Zimbabwe", Journal of Social Development in Africa, Vol. 15 No. 2, pp. 5-32.

[5]. Haralambos, M. and Holborn, M (2013)Sociology Themes and Perspectives

[6]. Harper Collins UK.

[7]. Hove, M., Ngwerume, E.T. \& Muchemwa, C., (2013). The Urban Crisis in Sub-Saharan Africa: A Threat to Human Security and Sustainable Development. Stability: International Journal of Security and Development. 2(1), p.Art. 7. DOI: http://doi.org/10.5334/sta.ap

[8]. Manyanhaire, I.O., Rwafa, R. and Mutangadura, J. (2011). A Theoretical Overview of the Growth Centre Strategy: Perspectives for Reengineering the Concept in Zimbabwe. Journal of Sustainable Development in Africa. 13(4):1-13.

[9]. Merton R.K. (1957) ( $2^{\text {nd }}$ Edition) Social Theory and Social Structure. Amazon Books. NY.

[10]. Mwamwenda. T. S. (2004).Educational psychology: an African perspective. Sandton, South Heinemann.

[11].Narayana, G., and J. F. Kantner (200). Doing the needful: the dilemma of India's population policy. Jastor, Chicago.

[12]. Nhede, T. N, (2013) The Zimbabwe growth point phenomenon Impact and implications on public service delivery. Administratio Publica Vol 21 No 4

[13].Patterson GR1, Dishion TJ, Yoerger K. (2000) Adolescent growth in new forms of problem behavior: macro- and micro-peer dynamics. Prev Sci. 1(1):3-13

[14].Ricci, L. (2012) Consilience: Urban Livelihood and Adaptive Capacity: Urban Development in Dar Es Salaam. The Journal of Sustainable Development 7(1) 46-63

[15].Seccombe, W. (2005) Family Forms in Modes of Production. Actuel Marx 1(37), 27-42

[16].Scott, I. (1982). Urban and spatial development in Mexico. Baltimore, MD: The Johns Hopkins University Press.

[17].Sibanda, B.M.C. 1985. Growth Points - A Focus for Rural Development in Zimbabwe. Agricultural Administration. 19:161-174.

[18]. Voice of America, January 20, 2016.

[19].Wegner, T (1993) Applied Business Statistics. Capetown: Juta and Company Ltd. 